\title{
ANALISIS PENGARUH INFLASI, PRODUK DOMESTIK BRUTO \\ DAN BAGI HASIL TERHADAP DANA PIHAK KETIGA \\ BANK UMUM SYARIAH DI INDONESIA TAHUN 2014-2019
}

\author{
Eliana Siti Sugiharti ${ }^{1 *}$, Neni Sri Wulandari ${ }^{2}$, Rumaisah Azizah Al Adawiyah ${ }^{3}$ \\ ${ }^{1}$ Program Studi Ilmu Ekonomi dan Keuangan Islam, Universitas Pendidikan \\ Indonesia,eliana.sugiharti@student.upi.edu \\ ${ }^{2}$ Program Studi Ilmu Ekonomi dan Keuangan Islam, Universitas Pendidikan Indonesia, \\ neni.wulandari@upi.edu \\ ${ }^{3}$ Program Studi Ilmu Ekonomi dan Keuangan Islam, Universitas Pendidikan Indonesia, \\ rumaisah.azizah@upi.edu
}

\begin{abstract}
Third-Party Funds for Islamic Commercial Banks in Indonesia have fluctuated with a positive trendline, even though the growth in total assets in Indonesia has slowed down and third-party funds are the main assets. The greater the third-party funds, the greater the banking assets. Position of third-party funds is important in the development of banking assets. This study aims to describe and examine the influence of inflation, gross domestic product, and profit-sharing on third-party funds for Islamic commercial banks in Indonesia for the period 2014-2019. The method used in this research is the descriptive-quantitative approach. The research sample consisted of eight Islamic Commercial Banks which are obtained based on purposive sampling with a period of six years. The method in this research is panel data regression analysis using EViews 9. The results of this study indicate that gross domestic product affects third party funds, inflation has no effect on third party funds and profitsharing does not affect third-party funds.
\end{abstract}

Keywords: Islamic Banks, Inflation, Third Party Funds, Gross Domestic Product, Profit Sharing.

\begin{abstract}
ABSTRAK
Dana Pihak Ketiga Bank Umum Syariah mengalami fluktuasi dan meningkat, pertumbuhan total aset di Indonesia mengalami perlambatan dan dana pihak ketiga merupakan komponen utama aset. Semakin besar dana pihak ketiga maka semakin besar pula aset perbankan. Maka posisi dana pihak ketiga menjadi penting dalam perkembangan aset perbankan. Penelitian ini bertujuan untuk melihat gambaran serta pengaruh Inflasi, Produk domestik bruto dan Bagi Hasil terhadap Dana pihak ketiga Bank Umum Syariah di Indonesia tahun 2014-2019. Metode penelitian yang digunakan dalam penelitian ini adalah metode deskriptif kuantitatif. Sampel penelitian berjumlah delapan Bank Umum Syariah yang diperoleh berdasarkan purposive sampling dengan periode penelitian selama enam tahun penelitian. Data yang digunakan adalah data sekunder. Metode yang digunakan analisis regresi data panel dengan Eviews 9. Hasil penelitian ini menunjukkan bahwa produk domestik bruto berpengaruh terhadap dana pihak ketiga, inflasi tidak berpengaruh terhadap dana pihak ketiga dan Bagi hasil tidak berpengaruh terhadap dana pihak ketiga. Hal yang dapat dilakukan Bank Syariah dalam meningkatkan Dana Pihak Ketiga yaitu meningkatkan kinerja dalam pelaksanaan kegiatannya dan memberikan pembiayaan kepada sektor riil sehingga pendapatan masyarakat dapat meningkat dan masyarakat dapat menyisihkan sebagian pendapatan untuk saving.
\end{abstract}

Kata Kunci: Bank Umum Syariah, Inflasi, Dana Pihak Ketiga, Produk Domestik Bruto, Bagi Hasil.

\footnotetext{
${ }^{1 *}$ Penulis Korespondensi
} 


\section{PENDAHULUAN}

Pada awal perkembangannya, Bank Syariah hadir sebagai tanggapan dari kelompok ekonomi dan para ahli perbankan muslim yang mencoba dalam memenuhi dorongan dari beragam pihak yang memiliki keinginan supaya pelaksanaan jasa transaksi keuangannya selaras dengan nilai, moral dan prinsip-prinsip Islam (Suryani, 2012). Pangsa pasar dari perbankan syariah yang ada di Indonesia memiliki nilai yang kecil apabila dibandingkan dengan negara lainnya yang sebagian besar share perbankan syariah di Malaysia pada akhir tahun 2019 sudah diatas $21 \%$. Salah satu faktor yang berpengaruh adalah rendahnya literasi mengenai keuangan islam yang dimiliki mayoritas penduduk Indonesia. Sebagai perbandingan, nilai market dibandingkan dengan Malaysia adalah mayoritas penduduk Indonesia memandang bahwa bank syariah hanya dikhususkan untuk kalangan orang islam semata, namun tidak demikian karena keuangan islam menawarkan sistem perekonomian yang berasaskan keadilan serta keterbukaan(Marsyaf, 2019). Data saat inimenunjukkan bahwa market share dari perbankan syariah di Indonesia pada tahun 2018 sekitar 5,7 persen (Septyaningsih \& Zuraya, 2018) dan meningkat pada awal 2020 dengan market share sebesar 8,29\%(Komite Nasional Keuangan Syariah, 2020). Peningkatan market share dari perbankan syariah tidak lepas dari kebijakan konversi bank umum daerah menjadi bank syariah, diantaranya adalah Bank Aceh Syariah dan Bank NTB Syariah.

Perlambatan aset bank tersebut disinyalir dikarenakan dua indikator, (1) karena terjadi penurunan dana pihak ketiga yang berasal dari masyarakat atau (2) ketidakmampuan bank dalam menghimpun dana pihak ketiga padahal komponen utama aset perbankan dapat dilihat melalui DPK, yaitu apabila semakin besar DPK maka akan semakin besar aset perbankan tersebut. Dengan adanya DPK, bank dapat menjalankan fungsinya sebagai lembaga intermediasi dengan baik. Dengan demikian diharapkan DPK yang diperoleh perbankan terus meningkat (Setiawan, 2015). Namun meskipun Dana Pihak Ketiga mengalami penambahan pada komposisinya tetapi apabila dilihat dari pertumbuhannya, Dana Pihak Ketiga mengalami penurunan.

Pertumbuhan dana pihak ketiga mengalami kenaikan dari tahun 2015 sebesar 2,44 persen menjadi 18,01 persen, namun dari tahun 2016 sampai 2018 mengalami penurunan pertumbuhan sebesar 18,01 menjadi 15,49 pada tahun 2017 dan 8,05 persen pada tahun 2018 kemudian mengalami kenaikan kembali pada tahun 2019. Hal ini menunjukkan bahwa Bank Umum Syariah belum optimal dalam menghimpun dana masyarakat. Dana pihak ketiga dapat menjadi indikasi tingkat kepercayaan masyarakat terhadap bank yang bersangkutan. Apabila semakin tinggi dana pihak ketiga menunjukkan bahwa masyarakat semakin percaya terhadap 
bank yang bersangkutan. Namun, apabila dana pihak ketiga semakin turun maka menunjukkan bahwa kepercayaan pada bank pula semakin menurun (Wulandari, 2013).

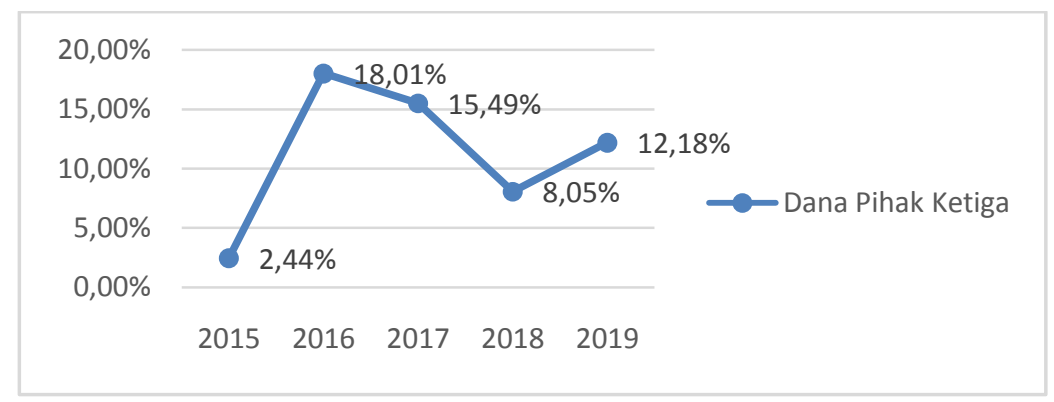

Gambar 1.

Pertumbuhan Dana Pihak Ketiga Bank Umum Syariah di Indonesia Tahun 2015-2019

Sumber: (data diolah)

Penurunan Dana Pihak Ketiga akan memengaruhi Pembiayaan Yang Disalurkan (PYD). Maka, perkembangan suatu bank dipengaruhi oleh kemampuannya dalam menghimpun dana dari masyakat. Sedangkan kemampuan perbankan syariah dalam menghimpun Dana Pihak ketiga yang bersaing dengan Perbankan Umum Konvensional di tengah perubahan-perubahan kondisi makroekonomi Indonesia akan turut menentukan besarkecilnya peran Perbankan syariah nasional dalam perekonomian negeri dan dalam industri Keuangan Syariah dunia yang semakin membesar (Muttaqiena, 2013).

Kondisi ekonomi makro akan mempengaruhi perusahaan dan masyarakat dalam bertransaksi dengan perbankan, ketika kondisi ekonomi membaik akan meningkatkan pula pendapatan masyarakat yang pada akhirnya akan meningkatkan jumlah Dana Pihak Ketiga (Panorama, 2016). Perbankan harus mengatasi inflasi yang melanda perekonomian Indonesia. Agar dapat menarik investor untuk berinventasi dan juga nasabah untuk dapat menyimpan uang mereka. Dengan adanya inflasi dapat memberikan keuntungan untuk bank sebab masyarakat lebih memilih untuk menyimpan uang mereka daripada untuk berbelanja barang (Meiliana \& M.N, 2020). Namun pernyataan di atas tidak sesuai dengan pernyataan Wulandari (2013) terhadap Dana Pihak Ketiga karena tingginya tingkat inflasi akan mendorong naiknya tingkat suku bunga pada bank konvensional guna menarik DPK, semakin tinggi suku bunga yang ditawarkan oleh bank konvensional, maka akan berpengaruh secara negatif terhadap total DPK BUS. 
Faktor yang mempengaruhi DPK adalah Produk Domestik Bruto (PDB). PDB menjadi indikator kegiatan produksi sebuah negara, dengan asumsi bahwa jika PDB naik, maka dapat menggambarkan kegiatan produksi negara tersebut meningkat (Saekhu, 2017). Maka masyarakat yang memiliki faktor produksi akan mendapatkan pendapatan yang lebih besar. Dampak dari meningkatnya PDB tersebut adalah berbanding lurus dengan jumlah dana yang dapat dialokasikan pada bank (saving). Pada akhirnya, hal tersebut dapat membuat sebuah bank lebih mudah didalam menjaring masyarakat sehinggga DPK akan mengalami peningkatan.

Selain faktor eksternal, terdapat faktor internal yang dapat mempengaruhi dana pihak ketiga, yaitu bagi hasil. Menurut Natalia (2014) adanya unsur bagi hasil membuat kinerja bank syariah menjadi transparan kepada nasabah, sehingga nasabah bisa memonitor kinerja bank syariah atas jumlah bagi hasil yang diperoleh. Adanya transparansi kinerja bank syariah akan menjadi pertimbangan tersendiri bagi nasabah untuk menempatkan dananya pada bank syariah atau pada bank konvensional (Mumtazah \& Septiarini, 2016).

Penelitian dana pihak ketiga ini menjadi penting karena pangsa pasar perbankan syariah indonesia kecil apabila dibandingkan dengan negara mayoritas penduduk muslim lainnya. Hal ini disebabkan karena dari pernyataan Otoritas Jasa Keuangan bahwa total asset perbankan syariah mengalami perlambatan dan dana pihak ketiga berperan sebagai prediksi terhadap asset sehingga dana pihak ketiga perlu ditingkatkan guna meningkatkan pula asset sehingga market share perbankan syariah akan meningkat pula, namun pada data yang ada bahwa dana pihak ketiga mengalami penurunan pada tahun 2018 meskipun kembali meningkat pada tahun 2019 sehingga dana pihak ketiga pada pertumbuhannya perlu ditingkatkan yang akan berpengaruh terhadap keberlangsungan operasional bank syariah.

Berdasarkan permasalahan di atas perlu diteliti mengingat pentingnya dana pihak ketiga yang merupakan modal utama perbankan syariah. Dengan meningkatnya pendapatan masyarakat memberikan kesempatan masyarakat untuk menyimpan dananya baik dalam bentuk tabungan ataupun deposito di bank. Berdasarkan masalah di atas maka penulis melakukan penelitian terkait dengan pengaruh inflasi, produk domestik bruto dan bagi hasil terhadap dana pihak ketiga bank umum syariah selama periode 2014-2019.

\section{LITERATUR REVIEW}

\section{Dana Pihak Ketiga}

Dana pihak ketiga (simpanan) berdasarkan UU Perbankan No. 10 tahun 1998 ialah dana yang telah dipercayakan masyarakat kepada bank yang berdasar kepada perjanjian 
penyimpanan dana, baik dalam bentuk tabungan, giro, sertifikat deposito, deposito, serta bentuk lainnya (Rivai, 2007). Sedangkan menurut Ismail, dana pihak ketiga ini biasanya lebih dikenal luas sebagai dana masyarakat, yang artinya adalah dana yang berasal dari masyarakat yang berhasil dihimpun bank dalam arti luas, istilah masyarakat tersebut meliputi individu, maupun badan usaha (Ismail, 2011). Dana pihak ketiga (DPK) merupakan dana yang berasal dari masyarakat dan/atau nasabah yang terdiri dari tabungan, giro, simpanan yang berjangka, sertifikat deposito serta kewajiban segera lainnya (Fitri, 2016).

Berdasarkan penjelasan di atas, dapat disimpulkan bahwa Dana Pihak Ketiga adalah dana masyarakat yang dihimpun bank meliputi masyarakat individu atau badan usaha dalam bentuk giro, tabungan, simpanan berjangka, sertifikat deposito dan kewajiban segera lainnya.

\section{Inflasi}

Menurut Bank Indonesia (2018), inflasi diartikan sebagai sebuah kenaikan harga secara umum serta terus menerus dalam jangka waktu tertentu. Kenaikan harga tidak dapat disebut sebagai inflasi kecuali jika kenaikan tersebut bersifat meluas (atau menyebabkan kenaikan harga) pada barang lainnya. Inflasi adalah gejala ekonomi yang menunjukkan naiknya tingkat harga secara umum yang berkesinambungan. Syarat inflasi yaitu terjadi kenaikan harga-harga secara masif dan terus menerus. Jika hanya satu atau dua jenis barang saja yang naik, itu bukan merupakan inflasi. Kenaikan harga yang bersifat sementara, umpamanya kenaikan harga karena musiman, menjelang hari raya, bencana, dan sebagainya, tidak disebut sebagai inflasi (Hasyim, 2016). Berdasarkan penjelasan di atas, dapat disimpulkan bahwa Inflasi merupakan kenaikan harga secara masif serta bersifat kontinyu (terus menerus) terhadap harga-harga barang secara umum dalam jangka waktu tertentu dan berlangsung cukup lama.

\section{Produk Domestik Bruto}

Gross Domestic Product (GDP) atau Produk Domestik Bruto (PDB) merupakan nilai dari barang dan jasa yang diproduksi dalam negeri yang bersangkutan untuk jangka waktu tertentu. Interpretasi pernyataan tersebut mencerminkan bahwa yang dihitung dalam kategori PDB tersebut adalah produk atau output berupa barang atau jasa dalam suatu perekonomian yang diproduksi oleh input atau faktor-faktor produksi yang dimiliki oleh warga negara bersangkutan maupun oleh warga negara asing yang tinggal di negara itu (Sunyoto, Hasanah, \& Danang, 2014). Menurut pendapat Sukirno (2015) Produk domestik bruto (PDB) ialah konsep dalam perhitungan pendapatan nasional. Dalam analisis makro ekonomi PDB selalu 
dikenal dengan istilah "pendapatan nasional (national income)" istilah tersebut menyatakan suatu nilai barang atau jasa yang dihasilkan suatu negara.

PDB akan menghitung hasil produksi dari barang serta jasa yang dapat dihasilkan oleh perusahaan atau orang asing yang beroperasi di wilayah negara yang bersangkutan. Barang-barang yang dihasilkan tersebut termasuk barang modal yang belum diperhitungkan biaya penyusutannya, karenanya jumlah yang dihasilkan dari PDB dianggap bersifat kotor atau bruto (Arif, 2014). Berdasarkan penjelasan di atas dapat tarik kesimpulan bahwa Produk Domestik Bruto adalah suatu nilai barang atau jasa yang dapat dihasilkan oleh unit-unit produksi pada suatu negara dalam periode tertentu.

\section{Bagi Hasil}

Sistem bagi hasil merupakan sistem dimana dilakukannya perjanjian atau ikatan bersama di dalam melakukan kegiatan usaha. Di dalam usaha tersebut diperjanjikan adanya pembagian hasil atas keuntungan yang di dapat antara kedua belah pihak atau lebih. Bagi hasil adalah bentuk return (perolehan aktivitas usaha) dari kontrak investasi dari waktu ke waktu, tidak pasti dan tidak tetap pada bank Islam. Besar kecilnya perolehan kembali itu tergantung pada hasil usaha yang benar-benar diperoleh bank Islam (Rivai \& Arifin, 2010). Menurut Ascarya (2011) Bagi hasil adalah sistem pembagian hasil usaha dimana pemilik modal bekerjasama dengan pemilik modal untuk melakukan kegiatan usaha. Apabila kegiatan usaha menghasilkan keuntungan maka dibagi berdua dan ketika mengalami kerugian ditanggung bersama pula. Sistem bagi hasil menjamin adanya keadilan dan tidak ada pihak yang tereksploitasi (Natalia et al., 2014). Menurut Ismail (2011) Bagi hasil adalah pembagian atas hasil usaha yang telah dilakukan oleh pihak-pihak yang melakukan perjanjian, yaitu pihak nasabah dan pihak bank syariah. Berdasarkan penjelasan di atas maka dapat ditarik kesimpulan bahwa bagi hasil adalah bentuk perolehan pembagian atas hasil usaha dimana pemilik modal bekerjasama untuk melakukan kegiatan usaha dengan pihak-pihak yang melakukan perjanjian yaitu pihak nasabah dan pihak bank syariah.

\section{METODE}

Metode yang digunakan dalam penelitian ini menggunakan pendekatan kuantitatif. Penelitian kuantitatif mengutamakan keberadaan angka dalam menyelesaikan permasalahan dalam suatu penelitian. Penelitian kuantitatif merupakan pendekatan yang menggunakan analisis data berbentuk angka atau numerik dengan tujuan mengembangkan teori, model matematis, dan hipotesis mengenai fenomena yang diteliti(Suryani \& Hendrayadi, 2015). 
Metode penelitian ini merujuk pada tema atau masalah yang sedang diteliti, sehingga melalui penelitian ini dapat diketahui secara jelas mengenai gambaran tentang variabel penelitian. Pendekatan kuantitatif di dalam penelitian ini berperan untuk menggambarkan kondisi seberapa besar nilai pengaruh serta gambaran keterkaitan antara variabel Inflasi, Produk Domestik Bruto dan Bagi Hasil terhadap Dana Pihak Ketiga (DPK) Bank Umum Syariah (BUS) di Indonesia.

\section{Populasi dan Sampel Penelitian}

Teknik pengambilan sampel menggunakan purposive sampling. Sampel yang digunakan terdapat delapan Bank Umum Syariah yaitu Bank Muamalat, Bank Syariah Mandiri, Bank Mega Syariah, BRI Syariah, Bank Syariah Bukopin, BNI Syariah, Bank Panin Dubai Syariah, dan BCA Syariah. Dalam penelitian ini menggunakan metode analisis regresi data panel. Menurut Basuki \& Prawoto (2016) regresi data panel merupakan teknik regresi yang menggabungkan data runtut waktu (time series) dengan data silang (cross section)

Analisis regresi data panel menjadi landasan analisis pengaruh inflasi, produk domestik bruto dan bagi hasil terhadap dana pihak ketiga bank umum syariah 2014-2019 karena berkaitan dengan sejauh mana variabel dalam fenomena DPK bank umum syariah berperan dalam kurun waktu tertentu. Dibutuhkan sebuah uji asumsi klasik, berupa multikolinieritas dan heteroskedastisitas.Analisis data yang akan dilakukan menggunakan aplikasi komputer yaitu program Microsoft Excel 2013 dan program pengolah data Eviews 9.

Model regresi data panel dinyatakan dalam bentuk berikut:

$$
Y_{i t}=\alpha+\beta_{1} X_{1 i t}+\beta_{2} X_{2 i t}+\beta_{3} X_{3 i t}+\beta_{4} X_{4 i t}+\epsilon_{i t}
$$

Keterangan:

$$
\begin{array}{ll}
\alpha & : \text { Konstanta } \\
\beta & : \text { Koefisien Regresi } \\
\in & : \text { Standar Kesalahan } \\
Y_{i t} & : \text { Dana Pihak Ketiga } \\
X_{1 i t} & : \text { Inflasi } \\
X_{2 i t} & : \text { Produk Domestik Bruto } \\
X_{3 i t} & : \text { Bagi Hasil }
\end{array}
$$




\section{HASIL DAN PEMBAHASAN}

Penelitian ini memiliki tujuan untuk mengetahui kondisi aktual serta pengaruh Dana Pihak Ketiga, Inflasi, Produk Domestik Bruto dan Bagi Hasil pada BUS di Indonesiaselama periode tahun 2014-2019.

\section{Hasil Penelitian}

Model yang sesuai untuk penelitian ini adalah model Fixed Effect Model (FEM). Berdasarkan hasil regresi dengan menggunakan Fixed Effect Model (FEM), maka persamaan matematis penelitian ini adalah:

$\mathrm{DPK}=-7.637957_{\mathrm{it}}+0.001342$ Inflasi $_{1 \mathrm{it}}+1.032031 \mathrm{PDB}_{2 \mathrm{it}}+0.058222$ Bagi Hasil $_{3 \mathrm{it}}+\varepsilon_{\mathrm{it}}$

Berdasarkan model regresi tersebut, dapat ditarik kesimpulan bahwa jika nilai dari variabel X1 (inflasi), X2 (produk domestik bruto), serta X3 (bagi hasil) adalah sebesar nol, maka variabel dana pihak ketiga (DPK) akan memiliki nilai sebesar $-7.637957 \%$. Selanjutnya, jika melihat persamaan regresi diatas juga memberikan kesimpulan bahwasannya setiap kenaikan sebesar $1 \%$ dari variabel X1 (inflasi), maka Y (dana pihak ketiga) akan naik sebesar $0.001342 \%$, kemudian setiap kenaikan sebesar $1 \%$ dari variabel X2

(produk domestik bruto), maka Y (dana pihak ketiga) akan naik sebesar $1.032031 \%$, dan setiap kenaikan sebesar 1\% dari variabel X3 (bagi hasil), maka Y (dana pihak ketiga) akan naik sebesar $0.058222 \%$.

\section{Hasil Uji F-Statistik}

Uji-F ini dilakukan untuk melihat pengaruh dari variabel inflasi, PDB dan bagi hasil terhadap variabel DPK secara bersama-sama dan simultan. Berdasarkan hasil analisis, didapatkan hasil analisis terkait uji-F sebagai berikut:

\section{Tabel 4}

\section{Hasil Uji-F Statistik}

\begin{tabular}{ll}
\hline F-statistic & $\mathbf{1 8 4 . 8 9 7 8}$ \\
\hline Prob(F-statistic) & $\mathbf{0 . 0 0 0 0 0 0}$ \\
\hline
\end{tabular}

Sumber: Hasil Analisis, 2020 
Berdasarkan hal tersebut, dengan hasil yang menunjukkan bahwa nilai Prob (FStatistic) memiliki nilai yang lebih kecil daripada nilai alpha $(\alpha=0.05)$, maka dapat disimpulkan bahwa variabel inflasi, PDB dan bagi hasil memiliki pengaruh terhadap variabel DPK secara simultan.

\section{Hasil Uji-t Statistik}

Berdasarkan hasil uji dengan menggunakan Eviews 9maka dijelaskan dalam pembahasan uji t berikut ini.

\section{a. Pengaruh Inflasi Terhadap Dana Pihak Ketiga}

Adapun hasil dari nilai t-hitung pada variabel Inflasi terhadap Dana Pihak Ketiga pada output analisis model regresi sebelumnya, maka pengaruh dari variabel inflasi secara individu terhadap variabel DPK didalam penelitian ini adalah sebagai berikut:

\section{Tabel 5}

\section{Hasil Uji-t Inflasi Terhadap Dana Pihak Ketiga}

\begin{tabular}{lllllll}
\hline Var. & Coeff. & Std. Error & t-Stat & Prob. & Kep. & Ket. \\
\hline Inflasi & 0.001 & 0.020 & 0.066 & 0.947 & Menerima $\mathrm{H}_{0}$ & Tidak Signifikan
\end{tabular}

Sumber: Data Hasil Penelitian (2020)

Berdasarkan hasil penelitian pada tabel 4.13, dapat terlihat bahwa nilai t-hitung variabel inflasi didalam model regresi penelitian ini adalah sebesar 0.066761. Jika melihat kriteria dari nilai t-tabel, nilai dari t-hitung memiliki nilai yang lebih kecil dibandingkan dengan nilai t-tabel, maka dapat disimpulkan bahwa hipotesis menerima $\mathrm{H}_{0}$ dan menolak $\mathrm{H} 1$. Kemudian, dengan melihat nilai probabilitas dari variabel inflasi, variabel tersebut memiliki nilai probabilitas 0.9471 yang lebih besar dibandingkan dengan nilai alpha $(\alpha=0.05)$. Berdasarkan hal tersebut, maka dapat disimpulkan bahwa secara parsial variabel inflasi tidak berpengaruh terhadap dana pihak ketiga (DPK) dari Bank Umum Syariah selama periode 2014-2019.

\section{b. Pengaruh Inflasi Terhadap Dana Pihak Ketiga}

Adapun hasil dari nilai t-hitung pada variabel Produk Domestik Bruto terhadap Dana Pihak Ketiga pada output analisis model regresi, maka pengaruh dari variabel inflasi secara individu terhadap variabel DPK didalam penelitian ini adalah sebagai berikut: 
Tabel 6

Hasil Uji-t PDB Terhadap Dana Pihak Ketiga

\begin{tabular}{lllllll}
\hline Var. & Coeff. & Std. Error & t-Stat & Prob. & Kep. & Ket. \\
\hline Inflasi & 1.032 & 0.250 & 4.114 & 0.0002 & Menolak H0 & Signifikan
\end{tabular}

Sumber: Data Hasil Penelitian (2020)

Berdasarkan hasil yang ditunjukkan pada tabel 4.15 , dapat terlihat bahwa nilai thitung variabel PDB didalam model regresi penelitian ini adalah sebesar 4.114632. Jika melihat kriteria dari nilai t-tabel, nilai dari t-hitung memiliki nilai yang lebih besar dibandingkan dengan nilai t-tabel, maka dapat disimpulkan bahwa hipotesis menolak $\mathrm{H}_{0}$. Kemudian, dengan melihat nilai probabilitas dari variabel inflasi, variabel tersebut memiliki nilai probabilitas 0.0002 yang lebih kecil dibandingkan dengan nilai alpha $(\alpha=0.05)$. Berdasarkan hal tersebut, maka dapat disimpulkan bahwa secara parsial variabel produk domestik bruto (PDB) memiliki pengaruh yang signifikan terhadap dana pihak ketiga (DPK) dari Bank Umum Syari’ah selama periode 2014-2019.

\section{c. Pengaruh Bagi Hasil Terhadap Dana Pihak Ketiga}

Adapun hasil dari nilai t hitung pada variabel Bagi Hasil terhadap Dana Pihak Ketiga pada output analisis model regresi, maka pengaruh dari variabel secara individu terhadap variabel DPK didalam penelitian ini adalah sebagai berikut:

Tabel 6

Hasil Uji-t Bagi Hasil Terhadap Dana Pihak Ketiga

\begin{tabular}{ccccccc}
\hline Var. & Coeff. & Std. Error & t-Stat & Prob. & Kep. & Ket. \\
\hline Inflasi & 0.058 & 0.043 & 1.327 & 0.192 & Menerima H0 & Tidak \\
\hline \multicolumn{5}{c}{ Sumber: Data Hasil Penelitian (2020) }
\end{tabular}

Dapat terlihat bahwa nilai t-hitung variabel bagi hasil didalam model regresi penelitian ini adalah sebesar 1.327382. Nilai dari t-hitung memiliki nilai yang lebih kecil jika dibandingkan dengan nilai t-tabel, maka dapat disimpulkan bahwa hipotesis menerima $\mathrm{H}_{0}$. Kemudian, dengan melihat nilai probabilitas dari variabel bagi hasil, variabel tersebut memiliki nilai probabilitas 0.1925 yang lebih besar dibandingkan dengan nilai alpha $(\alpha=$ 
0.05). Berdasarkan hal tersebut, maka dapat disimpulkan bahwa secara parsial variabel bagi hasil tidak memiliki pengaruh terhadap dana pihak ketiga (DPK) dari Bank Umum Syari'ah selama periode 2014-2019.

\section{Pengaruh Inflasi terhadap Dana Pihak Ketiga}

Inflasi dapat diartikan sebagai gejala kenaikan harga barang-barang yang bersifat umum dan terus menerus. Inflasi mencerminkan stabilitas ekonomi, Kenaikan harga barangbarang mengakibatkan inflasi meningkat, masyarakat cenderung mengurangi saving dan investasi. Oleh karena itu, akan mengurangi dana yang dihimpun oleh bank. Maka aset perbankan secara riil akan menurun, sehingga akan mempengaruhi kemampuan operasi perbankan dalam penyaluran pembiayaan.

Berdasarkan data pada gambaran umum menunjukkan bahwa perkembangan inflasi di Indonesia pada tahun 2014-2019 mengalami fluktuasi cenderung menurun. Pada tahun 2015 inflasi mengalami penurunan 3,35\% dari 2014 sebesar 8,36\%. Indonesia mengalami kenaikan serta penurunan angka inflasi setiap tahunnya. Hal ini disebabkan oleh harga-harga barang relatif terkendali seperti beras, juga kenaikan harga Bahan Bakar dan tarif tiket pesawat mulai meningkat

Dalam penelitian ini variabel inflasi tidak berpengaruh terhadap Dana Pihak Ketiga. Dana pihak ketiga yang dihimpun oleh bank syariah didominasi oleh akad berbasis bagi hasil. Sehingga pembagian hasil usaha akan sangat dipengaruhi oleh besar kecilnya hasil usaha yang dihasilkan oleh pengelola dana. Dengan kata lain, bagi hasil yang diterima oleh nasabah akan sangat tergantung pada pendapatan yang diperoleh bank syariah sebagai pengelola dana. Penelitian ini juga memperkuat penelitian lain yang menyatakan bahwa inflasi tidak berpengaruh terhadap tabungan (Haron \& Azmi, 2008), terhadap deposito di bank syariah (Novianto \& Hadiwidjojo, 2013), serta terhadap DPK secara keseluruhan (Riani, 2012). Berbeda halnya dengan bank konvensional yang terdampak langsung dari kenaikan inflasi yang juga akan menaikan tingkat suku bunga.

Dengan demikian, berdasarkan hasil temuan dalam penelitian ini yang dikaitkan dengan konsep teoritis dan didukung fakta empiris penelitian sebelumnya dapat disimpulkan bahwa Inflasitidak berpengaruh terhadap Dana Pihak Ketiga BankUmumSyariah di Indonesia, sehingga dari hasil penelitian ini telah sesuai dan mendukung beberapa hasil riset sebelumnya, diantaranya penelitian (Riani, 2012), (Rudiansyah, 2014), (Prastiwi, 2018), dan (Wulandari, 2013). 


\section{Pengaruh Produk Domestik Bruto terhadap Dana Pihak Ketiga}

Faktor eksternal lainnya yang mempengaruhi DPK adalah Produk Domestik Bruto (PDB). PDB menjadi indikator kegiatan produksi sebuah negara, dengan asumsi bahwa jika PDB naik, maka dapat menggambarkan kegiatan produksi negara tersebut meningkat (Saekhu, 2017). Dengan kata lain, perhitungan dari PDB menggambarkan kerangka perhitungan dengan tujuan untuk melihat aktivitas ekonomi yang tengah berlangsung pada kehidupan masyarakat (Amelia, 2009). Dengan meningkatnya pendapatan per kapita masyarakat, maka akan berdampak pula pada kecenderungan masyarakat untuk menyimpan sebagian pendapatannya ke bank.

Berdasarkan hasil analisis, Produk domestik bruto memiliki pengaruh positif dan signifikan terhadap dana pihak ketiga bank syariah, artinya semakin meningkat pendapatan yang diperoleh masyarakat dari kegiatan produksi semakin meningkatkan dana pihak ketiga bank syariah tersebut. Maka berdasarkan hasil penelitian disimpulkan bahwa apabila PDB naik, maka hal ini menggambarkan kegiatan produksi dalam negeri yang meningkat. Pada kondisi tersebut masyarakat sebagai pemilik faktor produksi secara agregat akan memperoleh pendapatan yang lebih besar, baik karena peningkatan pendapatan maupun karena perluasan penerima pendapatan. Akibatnya akan semakin banyak dana yang dapat dialokasikan untuk simpanan (saving). Hal ini akan membuat bank lebih mudah menjaring dana masyarakat sehingga dana pihak ketiganya akan mengalami kenaikan. Bank Syariah yang memiliki dana pihak ketiga yang besar menandakan bahwa semakin besar perolehan penghimpunan yang didapatkan bank, hal tersebut tentunya mengharuskan bank syariah dapat memberikan pembiayaan kepada sektor riil agar dapat meningkatkan produksi sehingga meningkatkan pula pendapatan masyarakat. Maka salah satu hal yang dapat dilakukan adalah memberikan pembiayaan kepada sektor riil yang selektif agar mampu mengembalikan pembiayaan sehingga dapat memperoleh dana pihak ketiga kembali.

Hasil penelitian ini sesuai dengan penelitian yang dilakukan oleh Tripuspitorini \& Setiawan (2020). Pendapatan masyarakat yang terus meningkat akan membuat mereka mampu melakukan pemenuhan akan kebutuhannya, bahkan dapat melebihi batas konsumsi. Sehingga kelebihan dana yang dimiliki masyarakat akan disimpan dalam bentuk simpanan sebagai antisipasi konsumsi di masa yang akan datang. Dapat juga dari kelebihan dana tersebut dipergunakan untuk investasi agar dapat menghasilkan keuntungan yang lebih besar (Tripuspitorini \& Setiawan, 2020)

Sementara itu, hasil analisis di dalam penelitian ini memiliki kesimpulan yang berbeda dengan (Fuadatis, 2018) yang menyimpulkan bahwa variabel pertumbuhan produk domestik 
bruto menunjukkan bahwa pertumbuhan produk domestik bruto tidak berpengaruh signifikan terhadap dana pihak ketiga. Penelitian lain dari (Jatnika, 2020) terkait dengan hubungan PDB terhadap DPK menunjukkan pengaruh negatif terhadap dana pihak ketiga bank umum syariah. Sementara hasil penelitian (Wulandari, 2013) dan (Muttaqiena, 2013) menunjukkan bahwa vaiabel PDB memiliki hubungan yang tidak signifikan terhadap DPK, hal ini dikarenakan bahwa tren masyarakat yang berinvestasi pada sektor investasi lain dibandingkan dengan meletakkan dananya pada sektor perbankan.

Berdasarkan penjelasan tersebut, maka dapat disimpulkan bahwa hasil dari penelitian ini terkait dengan pengaruh variabel Produk Domestik Bruto (PDB) memiliki hubungan positif yang signifikan terhadap variabel Dana Pihak Ketiga (DPK), yang mendukung penelitian dari (Saragih \& Esya, 2016), (Rudiansyah, 2014), (Noor, Utary, \& Fitriadi, 2017) dan (Saekhu, 2017) hal ini dikarenakan bahwa nilai dari produk domestik bruto selama periode 2014-2019 memiliki tren yang positif. Dengan peningkatan dari nilai tersebut, maka dapat mengindikasikan bahwa berdampak pada peningkatan nilai pendapatan masyarakat. Dengan kecenderungan peningkatan pendapatan ini, maka kelebihan masyarakat akan ditabung meningkatkan pula nilai dari DPK.

\section{Pengaruh Bagi Hasil terhadap Dana Pihak Ketiga}

Bagi hasil adalah bentuk return (perolehan aktivitas usaha) dari kontrak investasi dari waktu ke waktu, tidak pasti dan tidak tetap pada bank Islam. Besar kecilnya perolehan kembali itu tergantung pada hasil usaha yang benar-benar diperoleh bank Islam. Pada penelitian ini Bagi Hasil diukur berdasarkan pada data laporan keuangan triwulan yang dipublikasikan oleh masing-masing bank umum syariah melalui website bank tersebut.

Kondisi aktual dari bagi hasil pada bank-bank umum syariah menunjukkan bahwa perkembangan Bagi Hasil Bank Umum Syariah di Indonesia tahun 2014-2019 mengalami fluktuasi. Selain itu, di tiap tahunnya perkembangan Bagi Hasil bank syariah mengalami pertumbuhan yang berbeda-beda. Terdapat bank syariah pada periode penelitian yang memiliki pertumbuhan Bagi Hasil yang bersifat positif yaitu Bank Bukopin Syariah. Sedangkan tujuh di antaranya mengalami fluktuatif.

Berdasarkan hasil analisis, Bagi Hasil tidak memiliki pengaruh terhadap dana pihak ketiga bank umum syariah periode 2014-2019. Hal ini mengindikasikan bahwa beberapa masyarakat muslim dalam menempatkan dana pada bank syariah tidak hanya dipengaruhi oleh motif memperoleh keuntungan semata, namun juga dilandasi semangat untuk saling tolong menolong/tabarru'dalam menggerakkan sektor riil, serta adanya keyakinan yang kuat 
di kalangan masyarakat muslim bahwa bunga bank konvensional itu mengandung unsur riba yang dilarang agama Islam.Penelitian ini memiliki kesimpulan yang sama dengan penelitian dari (Riauwanto \& Sulastiningsih, 2019), (Novianto \& Hadiwidjojo, 2013)

Sementara itu, hasil analisis ini berbeda dengan hasil analisis (Aghnawati \& Cahyadin, 2019), (Mumtazah \& Septiarini, 2015), (Ferdiansyah, 2013), (Natalia, 2014) dan (Wulandari, 2014) yang menyebutkan bahwa bagi hasil berpengaruh signifikan terhadap dana pihak ketiga. Hal ini menunjukkan bahwa besar kecilnya bagi hasil yang diberikan bank umum syariah kepada masyarakat akan berpengaruh dengan besar kecilnya dana masuk dari masyarakat yang dititipkan atau di investasikan pada bank umum syariah tersebut.

Berdasarkan penjelasan tersebut, maka maka dapat disimpulkan bahwa hasil dari penelitian menunjukkan bahwa bagi hasil tidak memiliki pengaruh yang signifikan terhadap variabel Dana Pihak Ketiga (DPK) yang mendukung penelitian dari (Novianto \& Hadiwidjojo, 2013) dan (Riauwanto \& Sulastiningsih, 2019). Alasan ini memiliki asumsi bahwa nasabah menyimpan dananya di bank syariah karena alasan agama, dan kesesuaiannya dengan prinsip syariah. Sehingga nasabah loyalis tidak memperhatikan berapa return yang diberikan oleh bank tetapi bagi mereka adalah memenuhi perintah Allah SWT dengan menghindari riba

\section{KESIMPULAN}

Inflasi tidak berpengaruh terhadap Dana Pihak Ketiga. Hal ini karena Dana pihak ketiga yang dihimpun oleh bank syariah didominasi oleh akad berbasis bagi hasil. Sehingga pembagian hasil usaha akan dipengaruhi oleh besar kecilnya hasil usaha yang dihasilkan oleh pengelola dana. Dengan kata lain, bagi hasil yang diterima oleh nasabah akan bergantung pada pendapatan yang diperoleh bank syariah sebagai pengelola dana juga karena bank syariah tidak memakai mekanisme suku bunga, sehingga tingkat bagi hasil atau margin laba produk bank syariah tidak harus menyesuaikan dengan tingkat inflasi seperti halnya tingkat suku bunga bank konvensional. Hal ini mengindikasikan bahwa setiap adanya peningkatan atau penurunan Inflasi maka tidak akan berpengaruh terhadap peningkatan atau penurunan Dana Pihak Ketiga Bank Umum Syariah.

Produk domestik bruto berpengaruh terhadap Dana Pihak Ketiga. Hal ini karena nilai Produk Domestik Bruto menunjukkan tren positif sehingga terdapat peningkatan nilai pendapatan masyarakat. Dengan kecenderungan peningkatan pendapatan ini, maka kelebihan masyarakat akan ditabung yang mana meningkatkan pula nilai dari Dana Pihak Ketiga. Hal ini mengindikasikan bahwa setiap adanya peningkatan atau penurunan Produk Domestik 
Bruto maka akan berpengaruh terhadap peningkatan atau penurunan Dana Pihak Ketiga Bank Umum Syariah.

Bagi Hasil tidak berpengaruh terhadap Dana pihak ketiga. Hal ini karena masyarakat yang menyimpan tabungan di bank syariah tidak melihat dari return yang diterima, dan nasabah ini merupakan nasabah loyalis yang tidak memperhatikan keuntungan dalam menabung di bank syariah melainkan karena bank syariah melaksanakan kegiatannya dalam prinsip-prinsip syariah. Maka bank umum syariah yang mengalami peningkatan atau penurunan dari bagi hasil tidak akan mempengaruhi peningkatan atau penurunan dari Dana pihak ketiga bank umum syariah. Inflasi, produk domestik bruto, dan bagi hasil secara simultan berpengaruh dan signifikan terhadap dana pihak ketiga bank umum syariah di Indonesia.

\section{REFERENSI}

Arif, D. (2014). pengaruh Produk Domestik Bruto, Jumlah Uang Beredar, Inflasi dan BI rate terhadap Indeks Harga Saham Gabungan di Indonesia periode 2007-2013. Jurnal Ekonomi Bisnis, 19(3).

Ascarya. (2011). Akad dan Produk Bank Syariah. Jakarta: Rajawali Pers.

Basuki, A. T., \& Prawoto, N. (2016). Analisis Regresi dalam Penelitian. Ekonomi dan Bisnis : dilengkapi aplikasi SPSS dan Eviews. Depok: PT Raja Grafindo Persada.

Fitri, M. (2016). Peran Dana Pihak Ketiga Dalam Kinerja Lembaga Pembiayaan Syariah Dan Faktor-Faktor Yang Memengaruhinya. Economica: Jurnal Ekonomi Islam, 7(1), 73-95.

Haron, S., \& Azmi, W. N. . (2008). Determinants of Islamic and Conventional deposits in the Malaysian banking system. Managerial Finance, 9(34), 618-643.

Ismail. (2011). Perbankan Syariah. Jakarta: Kencana Pernamedia Group.

Jatnika, M. D. (2020). Pengaruh variabel makroekonomi terhadap dana pihak ketiga Bank Umum Syariah di Indonesia. Jurnal Muara Ilmu Ekonomi Dan Bisnis, 4(1), 164-173.

Mumtazah, W., \& Septiarini, D. (2016). Analisis Faktor-Faktor Yang Mempengaruhi Jumlah Dana Pihak Ketiga Pada Bank Umum Syariah Di Indonesia (Periode Triwulan I 2010Triwulan I 2015). Jurnal Ekonomi Syariah Teori Dan Terapan, 3(10), 800-815.

Muttaqiena, A. (2013). Analisis Pengaruh PDB, Inflasi, Tingkat Bunga, Dan Nilai Tukar Terhadap Dana Pihak Ketiga Perbankan Syariah Di Indonesia 2008-2012. Economics Development Analysis Journal, 2(3), 175-185.

Natalia, E., AR, M. D., \& Rahayu, S. M. (2014). Pengaruh Tingkat Bagi hasil Deposito Bank Syariah dan Suku Bunga Deposito Bank Umum terhadap jumlah Simpanan Deposito 
Mudharabah ( Studi Pada PT . Bank Syariah Mandiri Periode 2009-2012 ). Jurnal Adminitrasi Bisnis, 9(7), 1-7.

Novianto, A. S., \& Hadiwidjojo, D. (2013). Analisis Faktor-Faktor yang mempengaruhi penghimpunan deposito mudharabah Perbankan Syariah di Indonesia. Jurnal Aplikasi Manajemen, 66, 595-604.

Riani, W. (2012). Pengaruh Suku Bunga, Inflasi, Jumlah Layanan Syariah, Indeks Harga Saham Gabungan, dan Index Country Risk terhadap Dana Pihak Ketiga pada Perbankan Syariah Indonesia. Dinamika Ekonomi: Jurnal Kajian Ekonomi Dan Pembangunan, $8(2), 32-45$.

Riauwanto, S., \& Sulastiningsih. (2019). Pengaruh Total Aset dan bagi Hasil perbankan terhadap volume dana pihak ketiga (DPK) pada Bank Umum Syariah. Jurnal Riset Manajemen, 6(2), 131-146.

Rivai, V., \& Arifin, A. (2010). Islamic Banking. Jakarta: PT. Bumi Aksara.

Rudiansyah, A. (2014). Pengaruh inflasi, BI rate, PDB dan nilai tukar rupiah terhadap simpanan mudharabah pada Bank Syariah di Indonesia. Jurnal Ilmu Manajemen, 2(2), $306-317$.

Saekhu. (2017). Dampak Indikator Makroekonomi terhadap Dana Pihak Ketiga Perbankan Syariah. Economica: Jurnal Ekonomi Islam Islam, 8(1), 103-130.

Saragih, A. Y., \& Esya, L. (2016). Pengaruh Kinerja Makroekonomi terhadap Dana Pihak Ketiga Bank Syariah Indonesia. Media Ekonomi, 24(2), 151-160.

Septyaningsih, I., \& Zuraya, N. (2018). Penyebab Perkembangan Bank Syariah di Indonesia Lambat. Retrieved May 16, 2020, from Republika website: https://www.republika.co.id/berita/ekonomi/syariah-ekonomi/18/12/08/pjdd1q383penyebab-perkembangan-bank-syariah-di-indonesia-lambat

Sukirno, S. (2015). Makro Ekonomi. Jakarta: PT Raja Grafindo Persada.

Sunyoto, Hasanah, E. U., \& Danang. (2014). Pengantar Ilmu Ekonomi Makro (Teori dan Soal). Yogyakarta: CAPS.

Suryani, \& Hendrayadi. (2015). Metode Riset Kuantitatif Teori dan Aplikasi Pada Penelitian Bidang Manajemen dan Ekonomi Islam. Jakarta: Prenada Media Group.

Suryani, S. (2012). Sistem Perbankan Islam di Indonesia: Sejarah dan Prospek Pengembangan. Muqtasid: Jurnal Ekonomi Dan Perbankan Syariah, 3(1), 111.

Tripuspitorini, F. A., \& Setiawan. (2020). Tripuspitorini, Fifi Afiyanti Setiawan. Jurnal Riset Akuntansi Dan Keuangan, 8(1), 121-132. 